\title{
Original
}

\section{Comparison of Five Growth Curve Models for Describing the Growth of Okinawa Agu Boars}

\author{
Shihei Touma ${ }^{1,2}$ and Motoharu Oyadomari ${ }^{1,2}$ \\ ${ }^{1}$ Okinawa Prefectural Livestock and Grassland Research Center, Nakijin, Okinawa 905-0426, Japan \\ Present address : ${ }^{2}$ Okinawa Prefectural Livestock Division, Naha, Okinawa 900-8570, Japan
}

(Received: July 1, 2020, Accepted : September 7, 2020)

\begin{abstract}
Okinawa Agu pigs are only raised in the Okinawa prefecture and are characterized by low growth performance and high-quality meat. This breed is often utilized as terminal boars for commercial pork production. The objective of this study was to investigate the growth pattern of Agu boars to inform their management. Five nonlinear growth models (Logistic, Gompertz, von Bertalanffy, Richards, and Janoschek) were used to describe the growth pattern of this breed. Animals were allowed ad libitum access to feed to 16 weeks of age and then reared under restricted feeding of $1.5 \mathrm{~kg} /$ day to 34 weeks of age. From birth to 34 weeks, body weight (BW) data of 14 Agu pigs were collected weekly. A comparison among the five models revealed that the Richards model was the best fit to the growth data based on the adjusted R-square and Akaike's information criterion. In the leaveone-out cross-validation, the Richards model was also superior in predicting the accuracy. According to the Richards function, Agu boars reached the inflection point of the maximum growth rate at 11.6 weeks at a BW of $29.6 \mathrm{~kg}$. The maximum growth rate of Agu boars was $496.9 \mathrm{~g} /$ day.
\end{abstract}

Jpn. J. Swine Science, 58, $1: 10-18$

Key words : Okinawa Agu pigs, growth curve, boars, body weight, nonlinear models

\section{Introduction}

The growth of animals shows a sigmoid curve, which increases rapidly at first, then gradually slows down, and eventually reaches a plateau. A few parameters can be varied in growth curves to represent different growth patterns. Several growth curve functions have been used to describe growth patterns in animal species (Brown et al., 1976 ; BeIKI et al., 2013 ; Luo et al., 2015).

Okinawa Agu pigs are only raised in Okinawa prefecture, which is the southernmost prefecture in Japan, and they are characterized by good meat quality (Touma et al., 2017). This breed was on the verge of extinction in the 1980s because of foreign pig breeds becoming widespread. Recently, the demand for Agu pork has increased with the growing desire among consumers for this delicacy. For commercial pork production, Agu pigs are often used as terminal boars in crosses with modern pig breeds (Touma et al., 2020). Boars need to gain an appropriate amount of weight during the growing period because being overweight leads to reduced libido and difficulty mounting a sow or dummy and having excessive growth restriction leads to a decline in the semen quality and a reduction in the number of sperms (NARO, 2013). Agu pigs are smaller and slower growing than improved modern breeds. Thus, developing Agu pigs are managed according to a specific

連絡者：當眞嗣平（E-mail : toumashh@pref.okinawa.lg.jp TEL. 098-866-2269) 
feeding management regimen (Okinawa Agu Brand Pork Promotion Council, 2008). There is limited information available regarding growth curves in Agu pigs. Yet, a suitable growth model offers producers a good indicator of the growth and growth characteristics of Agu boars, which can inform the development of more appropriate feeding management. We fitted five nonlinear models to determine the model that best describes the growth pattern of Agu boars.

\section{Material and Methods}

Experimental procedures for animal care and use were conducted at the Okinawa Prefectural Livestock and Grassland Research Center in Japan, according to the guidelines for proper conduct of animal experiments of the Science Council of Japan.

\section{Animals and Management}

A total of 14 Agu purebred boars derived from five sows were investigated in this study. The experiment was performed from April in 2015 to February in 2016. Pigs were cared for following the manual for feeding and managing Okinawa Agu pigs (Okinawa Agu Brand Pork Promotion Council, 2008). Pigs were weighted at birth and $1 \mathrm{~m} l$ of iron (with $200 \mathrm{mg}$ of dextran iron) was administered intramuscularly at 2 days after birth.
The piglets were weaned at 25 days of age. Pigs from the same litter were reared together from birth to 16 weeks. From birth to seven weeks of age, the pigs were housed in farrowing pens, and from 7 to 16 weeks of age, they were grouphoused, with three to four pigs per pigpen of $2.7 \times$ $2.7 \mathrm{~m}$. After 16 weeks, they were housed individually in single pens of $2.7 \times 1.2 \mathrm{~m}$. The pigs were fed five commercial diets during five different time intervals: three days to 4 weeks (first stage), 4-6 weeks (middle stage), 6-10 weeks (late stage), 1016 weeks, and 16-34 weeks. The ingredients and chemical composition of the experimental diets are presented in Table 1. Until 16 weeks of age, the pigs were allowed ad libitum access to feed, and thereafter, they were reared under restricted feeding of $1.5 \mathrm{~kg}$ per day. Feeding was done manually. The pigs were provided with free access to water throughout, and they were weighed weekly from birth to 34 weeks of age. The final data set comprised 490 records of body weights (BW) from 14 animals.

\section{Correction of body weight data}

JMP software (SAS Institute Inc.) was used to correct BW data before fitting to the growth functions. To remove the sow effects, the sow effects at each week of age were predicted using the random model:

Table 1. Ingredients and chemical composition of experimental diets

\begin{tabular}{|c|c|c|c|c|c|}
\hline \multirow[b]{2}{*}{ Type of diet } & \multicolumn{3}{|c|}{ Synthetic milk (3 days to $10 \mathrm{wks}$ ) } & \multirow{2}{*}{$\frac{10 \text { to } 16 \text { wks }}{\text { Growing }}$} & \multirow{2}{*}{$\frac{16 \text { to } 34 \text { wks }}{\text { Breeding }}$} \\
\hline & First stage & Middle stage & Late stage & & \\
\hline \multicolumn{6}{|l|}{ Ingredients (\%) } \\
\hline Animal origin feeds & 42 & 20 & 6 & 5 & 5 \\
\hline Grains & 34 & 50 & 66 & 68 & 66 \\
\hline Oil seed meal & 11 & 23 & 21 & 16 & 6 \\
\hline $\begin{array}{l}\text { Brans and food processing } \\
\text { by-products }\end{array}$ & 0 & 0 & 0 & 4 & 17 \\
\hline Others & 13 & 7 & 7 & 7 & 6 \\
\hline Total digestible nutrients (\%) & 87.0 & 84.5 & 79.5 & 78.0 & 73.0 \\
\hline Crude protein (\%) & 21.0 & 20.5 & 18.0 & 15.0 & 13.0 \\
\hline Crude fat (\%) & 4.0 & 3.5 & 3.0 & 2.0 & 1.5 \\
\hline Crude fiber (\%) & 2.0 & 3.0 & 4.0 & 5.0 & 9.0 \\
\hline Crude ash (\%) & 8.0 & 8.0 & 7.0 & 9.0 & 10.0 \\
\hline
\end{tabular}


Table 2. Equations of the five growth models and their derived parameters

\begin{tabular}{|c|c|c|c|c|}
\hline \multirow[b]{2}{*}{ Model } & \multirow[b]{2}{*}{ Equation } & \multicolumn{3}{|c|}{ Inflection point } \\
\hline & & Weeks of age & Weight & Daily weight gain \\
\hline Logistic & $y_{t}=A /\left(1+B e^{-k t}\right)$ & $\ln (B) / k$ & $A / 2$ & $k W / 14$ \\
\hline Gompertz & $y_{t}=A \exp \left(-B e^{-k t}\right)$ & $\ln (B) / k$ & $A / e$ & $k W / 7$ \\
\hline von Bertalanffy & $y_{t}=A\left(1-B e^{-k t}\right)^{3}$ & $\ln (3 B) / k$ & $8 A / 27$ & $3 k W / 14$ \\
\hline Richards & $y_{t}=A\left(1-B e^{-k t}\right)^{M}$ & $(-1 / k) \ln |1 / M B|$ & $A(M-1 / M)^{M}$ & $M k W\left[\left((M-1 / M)^{M}\right)^{-1 / M}-1\right] / 7$ \\
\hline Janoschek & $y_{t}=A-\left(A-W_{0}\right) \exp \left(-k t^{M}\right)$ & $(M k /(M-1))^{-1 / M}$ & $A-\left(A-W_{0}\right) \exp (-(M-1) / M)$ & {$\left[M k(A-W)\left((M-1) /(M k)^{(1 / M)}\right)^{(M-1)}\right] / 7$} \\
\hline
\end{tabular}

$\mathrm{Y}_{\mathrm{t}}$, body weight $(\mathrm{kg})$ at age $\mathrm{t}$ (weeks); $\mathrm{A}$, weight at maturity $(\mathrm{kg})$; $\mathrm{B}$, integration constant; $\mathrm{k}$, maturation rate; $\mathrm{M}$, inflection parameter; exp, base of the natural logarithm (2.7183); $\mathrm{W}_{0}$, the weight at birth; W, inflection point body weight.

Table 3. Descriptive statistics of least square means and standard deviations of the body weight of Agu boars

\begin{tabular}{cccccccccc}
\hline \hline Week & $\mathrm{n}$ & $\mathrm{BW}$ & $\mathrm{SD}$ & $\mathrm{CV}$ & Week & $\mathrm{n}$ & $\mathrm{BW}$ & $\mathrm{SD}$ & $\mathrm{CV}$ \\
\hline 0 & 14 & 1.11 & 0.14 & 0.13 & 18 & 14 & 52.0 & 5.70 & 0.11 \\
1 & 14 & 2.16 & 0.35 & 0.16 & 19 & 14 & 54.8 & 5.02 & 0.09 \\
2 & 14 & 3.79 & 0.73 & 0.19 & 20 & 14 & 56.8 & 5.09 & 0.09 \\
3 & 14 & 5.19 & 0.99 & 0.19 & 21 & 14 & 58.8 & 5.02 & 0.09 \\
4 & 14 & 7.10 & 1.06 & 0.15 & 22 & 14 & 60.3 & 5.21 & 0.09 \\
5 & 14 & 9.39 & 1.19 & 0.13 & 23 & 14 & 61.4 & 5.46 & 0.09 \\
6 & 14 & 11.9 & 1.67 & 0.14 & 24 & 14 & 63.6 & 6.17 & 0.10 \\
7 & 14 & 14.9 & 1.81 & 0.12 & 25 & 14 & 65.1 & 6.49 & 0.10 \\
8 & 14 & 17.6 & 2.33 & 0.13 & 26 & 14 & 67.3 & 6.40 & 0.10 \\
9 & 14 & 20.7 & 2.44 & 0.12 & 27 & 14 & 69.3 & 5.93 & 0.09 \\
10 & 14 & 23.8 & 2.63 & 0.11 & 28 & 14 & 71.2 & 6.14 & 0.09 \\
11 & 14 & 27.0 & 3.32 & 0.12 & 29 & 14 & 72.5 & 5.71 & 0.08 \\
12 & 14 & 30.4 & 3.60 & 0.12 & 30 & 14 & 74.2 & 5.23 & 0.07 \\
13 & 14 & 34.2 & 4.20 & 0.12 & 31 & 14 & 76.0 & 5.03 & 0.07 \\
14 & 14 & 38.2 & 4.73 & 0.12 & 32 & 14 & 77.6 & 4.67 & 0.06 \\
15 & 14 & 41.2 & 5.29 & 0.13 & 33 & 14 & 79.0 & 5.85 & 0.07 \\
16 & 14 & 44.7 & 5.50 & 0.12 & 34 & 14 & 80.8 & 6.30 & 0.08 \\
17 & 14 & 50.1 & 6.73 & 0.13 & & & & \\
\hline
\end{tabular}

$$
y_{i j}=\mu+a_{i}+e_{i j},
$$

where $y_{i j}$ is the $j$ th pig within the $i$ th sow ; $\mu$ the overall mean ; $a_{i}$ the effect of $i$ th sow ; and $e_{i j}$ the random error. The corrected BW was then estimated by $y_{i j}-\hat{a}_{i}$, where $\hat{a}_{i}$ is predictors for $a_{i}$. This corrected BW was fitted to the growth curve models.

\section{Growth Curve Models}

The growth curve models used in this study were the Logistic (WELlock et al., 2004), Gompertz (Gompertz, 1825), von Bertalanffy (von Bertalanffy, 1957) Richards (Fitzhugh, 1976), and Janoschek models (WELLOCK et al., 2004). The equations and their derived parameters are presented in Table 2. $Y_{t}$ represents the body weight (kg) at age $t$ (weeks), $A$ is the weight at maturity (kg), $B$ is an integration constant, $k$ is the maturation rate, and $M$ is the inflection parameter, which is specific to the Richards and Janoschek models. A negative correlation between $A$ and $k$ values was reported (BRown et al., 1976) ; a correlation analysis was also performed in this study. The estimation of the nonlinear growth curves was performed using the nls function of R 3.4.2 (R CORE TEAM 2017). Individ- 
ual body weight was used to estimate each growth curve parameter.

It is inappropriate to compare parameters between different models because the parameters of the growth curve have different mathematical meanings (SelvagGi et al., 2017). However, as the values of the parameters provide important information about the characteristics of Agu pigs, we have presented them in Table 6 .

The goodness of fit of the five growth models was compared using the adjusted coefficient of determination $\left(A d j R^{2}\right.$ ) and Akaike's information criterion (AIC). Further, the model prediction accuracy was evaluated using the leave-one-out cross-validation (HASTIE et al., 2009). One pig was left out from the 14 pigs for validation and the remaining 13 animals were used to estimate the parameters of each growth model to obtain the predictions for each week of age. The root mean square error (RMSE) and correlation $\left(r_{\mathrm{y} \hat{y}}\right)$ were calculated from the predicted and observed values of the one excluded for validation. This was repeated 14 times so that all animals had one validation data, and the average of the RMSE and $r_{y \hat{y}}$ was used as a measure of the accuracy of the prediction of the growth models.

\section{Results}

Table 3 shows the least square means, SD, and $\mathrm{CV}$ of $\mathrm{BW}$. The CVs showed a decreasing trend with weekly age. The $\mathrm{AdjR}^{2}$ ranged from 0.991 for the Logistic model to 0.997 for the Richards model (Table 3). The Richards model had the smallest AIC value, followed by the Gompertz, von Bertalanffy, Janoschek, and Logistic models (Table 4). Regarding the leave-one-out cross-validation, the correlations $\left(\mathrm{r}_{\mathrm{y} y}\right)$ were high in all models, ranging from 0.994 to 0.997 , and RMSE was the smallest for the Richards and largest for the Logistic model (Table 5).

The growth curves showed a typically sigmoid shape (Fig. 1). The residual plots based on the five growth curves generally showed the same pattern of behavior (Fig. 2). However, the pattern differed in the early weeks of age: from birth to six weeks of age, the Logistic model tended to overestimate BW, and the von Bertalanffy model tended to underestimate it (Fig. 1 and Fig. 2). The five models provided differing estimates of birth weight of 4.5, $0.6,1.9,1.2$, and $1.4 \mathrm{~kg}$ for the Logistic, von Bertalanffy, Gompertz, Richards, and Janoschek models, respectively, compared with the actual weight of $1.1 \mathrm{~kg}$. The value estimated by the Logistic model was four times higher than the actual value and that estimated using the Richards model was the most accurate among the five models.

Table 6 shows the growth curve parameters and inflection point traits of the five growth models. The largest $A$ value $(94.1 \mathrm{~kg})$ was found for the von Bertalanffy model and the lowest $(78.5 \mathrm{~kg})$

Table 4. Adjusted R-square (Adj $\mathrm{R}^{2}$ ), Akaike's information criterion (AIC) of the five models

\begin{tabular}{cccccc}
\hline \hline & \multicolumn{5}{c}{ Models } \\
\cline { 2 - 6 } & Logistic & Gompertz & von Bertalanffy & Richards & Janoschek \\
\hline AIC & 162.177 & 131.140 & 131.789 & 128.485 & 132.436 \\
AdjR $^{2}$ & 0.991 & 0.996 & 0.996 & 0.997 & 0.996 \\
\hline
\end{tabular}

Table 5. Root mean square error (RMSE) and the correlation between predicted and observed values $\left(r_{y \hat{y}}\right)$ of the five models

\begin{tabular}{cccccc}
\hline \hline & \multicolumn{5}{c}{ Models } \\
\cline { 2 - 6 } & Logistic & Gompertz & von Bertalanffy & Richards & Janoschek \\
\hline RMSE & 4.67 & 4.27 & 4.27 & 4.26 & 4.29 \\
$r_{y \hat{y}}$ & 0.994 & 0.997 & 0.997 & 0.997 & 0.997 \\
\hline
\end{tabular}



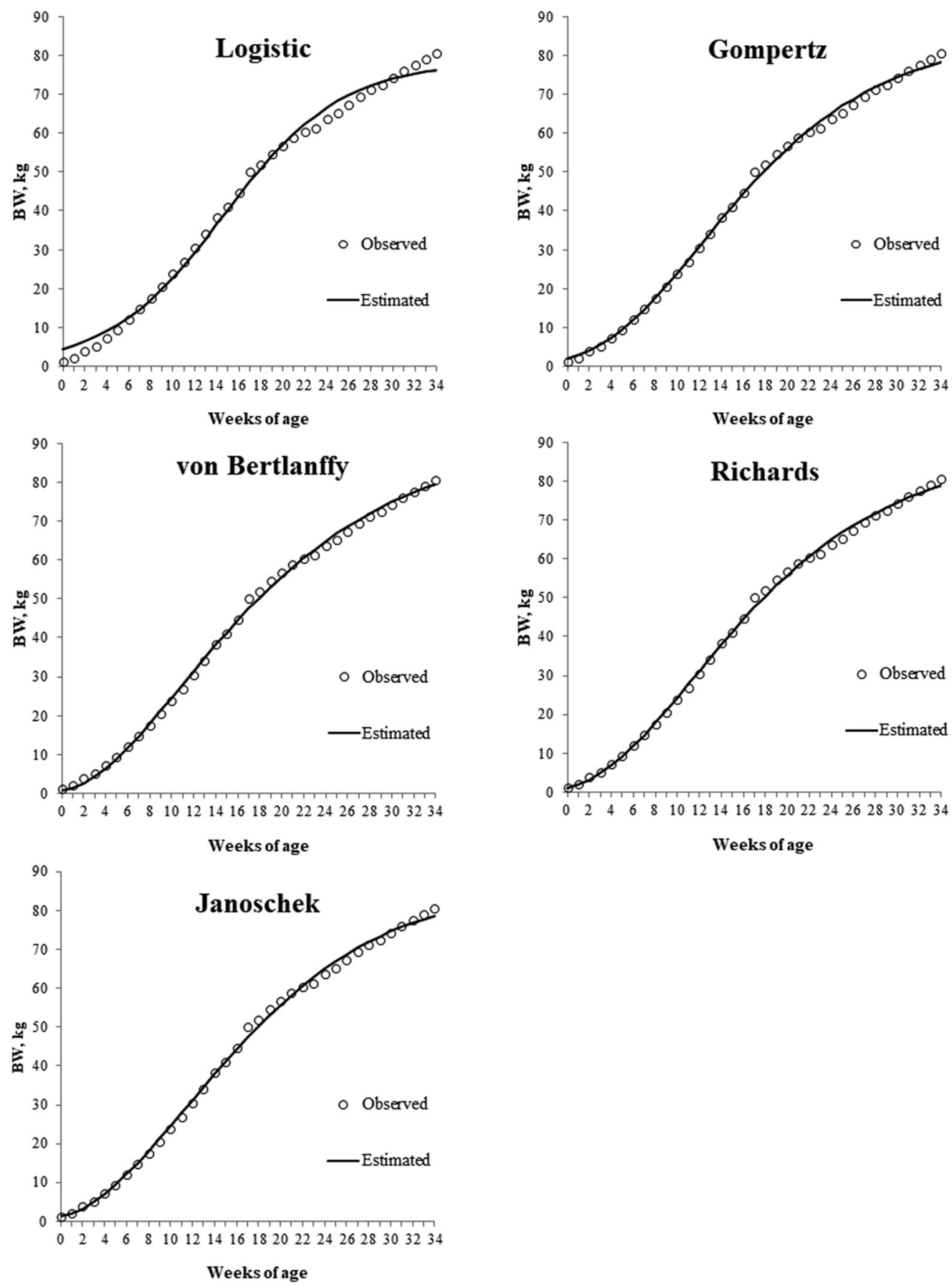

Fig. 1. Growth curves of Agu boars estimated using the Logistic, Gompertz, von Bertlanffy, Richards and Janoschek models.

was in the Logistic model (Table 6). The von Bertalanffy model indicated the slowest growth rate with a $\mathrm{k}$ value of 0.08 and the Logistic model indicated the fastest growth rate with a $\mathrm{k}$ value of 0.19. A moderate to strong negative correlation, ranging from -0.58 to -0.89 was observed between $A$ and $k$ values except for the Janoschek model. The age at the inflection point estimated by the Logistic model was later (14.8 weeks) than that of the other four model estimates of 11.1-12.4 weeks. The highest weight $(39.3 \mathrm{~kg})$ at the inflection point was estimated by the Logistic model, and the weights obtained from the Gompertz, von Bertalanffy, Richards, and Janoschek models were 


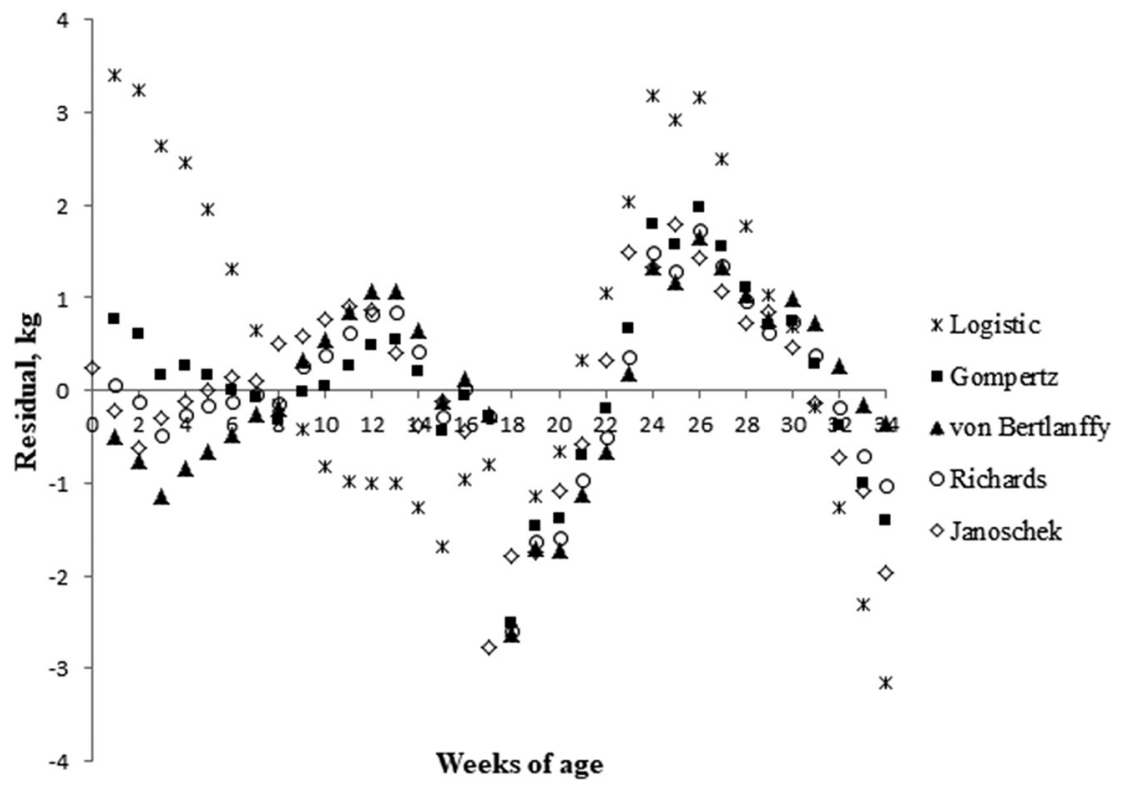

Fig. 2. Plot of the mean residuals of the estimated body weight from the observed body weight.

32.0, 27.1, 29.6, and $29.9 \mathrm{~kg}$, respectively. The maximum growth rate of Agu boars at the inflection point ranged from 484.6 to $553.1 \mathrm{~g} /$ day.

\section{Discussion}

In this study, five nonlinear growth models were used to describe the growth pattern of Agu boars. These five functions have been frequently used to represent the growth curve of pigs (WELLOCK et al., 2004 ; Kebreab et al., 2007 ; KöHn et al., 2007 ; Luo et al., 2015), and they described the growth of Agu boars reasonably well. However, during the early weeks of growth: from birth to six weeks of age, the Logistic and von Bertalanffy functions overestimated and underestimated BW, respectively. The Richards model provided the best fit with the highest $\mathrm{AdjR}^{2}$ and lowest AIC values among the five models. The Richards model also provided a relatively less-biased fit at all ages based on the residuals of the estimated versus observed values (Fig. 2). In addition, according to the leave-one-out cross-validation, the RMSE of the Richards model was the smallest, indicating that the Richards model yielded the best prediction accuracy, whereas the Logistic, Gompertz, and von Bertalanffy models are three-parameter functions with fixed inflection points, the Richards model has four parameters, and it can flexibly represent the inflection point (Kebreab et al., 2007 ; KöHn et al., 2007 ; SelvagGi et al., 2017). The flexibility of the Richards model probably led to a better depiction of the growth curve and improved accuracy. KeBREAB et al. (2007) reported that the Richards model provided a better fit than the Monomolecular, Gompertz, and von Bertalanffy models in the growth of Landrace $\times$ Yorkshire $\times$ Duroc and Landrace $\times$ Large White $\times$ Pietrain or Large White pigs. The Richards model also had a better fit than the Janoschek, which has four parameters same as those for Richards model. This result was consistent with that reported by KöHn et al. (2007) who applied the Logistic, Gompertz, Brody, Janoschek, and Richards models to describe the growth pattern of the Goettingen minipig and found that the Richards model provided the best fit.

The present study revealed that the Richards model accurately represents the weight changes in young Agu boars. This model can be used by farmers as a growth standard to assess the growth rate and determine the amount of feed.

In general, the mature weight of Agu pigs is considered to be around $100 \mathrm{~kg}$ : at the Okinawa Prefectural Livestock and Grassland Research Center in 2015, the mean weight of seven Agu 
Table 6. Means and standard errors of the growth curve parameters and inflection point traits of the five models

\begin{tabular}{cccccc}
\hline \hline & \multicolumn{5}{c}{ Models } \\
\cline { 2 - 6 } & Logistic & Gompertz & von Bertalanffy & Richards & Janoschek \\
\hline A & $78.5 \pm 1.54$ & $86.9 \pm 2.05$ & $94.1 \pm 4.59$ & $90.2 \pm 2.20$ & $86.7 \pm 2.14$ \\
B & $16.6 \pm 0.62$ & $3.87 \pm 0.07$ & $0.82 \pm 0.03$ & $0.28 \pm 0.21$ & - \\
k & $0.19 \pm 0.004$ & $0.11 \pm 0.003$ & $0.08 \pm 0.003$ & $0.09 \pm 0.006$ & $0.007 \pm 0.001$ \\
M & - & - & - & $3.79 \pm 1.93$ & $1.70 \pm 0.04$ \\
W & - & - & - & - & $1.36 \pm 0.26$ \\
t & $14.8 \pm 0.40$ & $12.4 \pm 0.49$ & $11.1 \pm 0.59$ & $11.6 \pm 0.62$ & $11.7 \pm 0.59$ \\
W & $39.3 \pm 0.77$ & $32.0 \pm 0.75$ & $27.1 \pm 0.91$ & $29.6 \pm 1.22$ & $29.9 \pm 1.06$ \\
G & $553.1 \pm 12.7$ & $500.4 \pm 12.4$ & $490.4 \pm 12.6$ & $496.9 \pm 12.9$ & $484.6 \pm 12.6$ \\
\hline
\end{tabular}

$\mathrm{A}$, size at maturity (kg); $\mathrm{B}$, integration constant; $\mathrm{k}$, maturation rate; $\mathrm{M}$, inflection parameter; $\mathrm{W}_{0}$, the weight at birth; t, Inflection point week of age; W, Inflection point body weight; G. Inflection point daily weight gain.

boars over 3 years of age was $104 \mathrm{~kg}$ (unpublished data). The mature weights estimated from this study ranged from 78.5 to $94.1 \mathrm{~kg}$, indicating that the five growth functions underestimated the mature weight of Agu boars, which is probably due to the short duration of the experiment. The experimental period was set to 8 months of age when general Agu boars start mating because this study focused on the growth during the growing period. However, StRathe et al. (2010) recommended that long-term measurement until weight gain reaches a plateau is needed to estimate the mature size of the animals accurately.

The moderate to strong negative correlation that was found between $A$ and $k$ values indicates that heavier adult Agu pigs tend to be late maturing and vice versa. This result was consistent with a previous study on beef cattle (BRown et al., 1976).

At the inflection point, the growth rate is maximized, and the speed of growth shifts from acceleration to deceleration (BRODY 1945). This study revealed that Agu boars reached their inflection point at 11.6 weeks, and the body weight at this time was $29.6 \mathrm{~kg}$, according to the best-fit Richards model. These results largely differed from those of StRathe et al. (2010), who reported that the inflection point for boars of three-way crossed pigs (crosses of Yorkshire $\times$ Landrace sows and Duroc boars) was $135 \mathrm{~kg}$ at 164 days (23 weeks), indicating that Agu boars reach the inflection point at a younger age than modern commercial breeds.

In conclusion, our study revealed that the Richards model provides the best fit to describe the growth pattern of young Agu boars when comparing the five growth models. Agu boars reached the inflection point of the maximum growth rate at 11.6 weeks with a BW of $29.6 \mathrm{~kg}$. The findings of this study can help farmers determine whether their young Agu boars are growing appropriately.

\section{References}

Beiki, H., A. Pakdel, M. Moradi-shahbabak and H. MeHrban : 2013, Evaluation of growth functions on Japanese quail lines, J. Poult. Sci., 50, 20-27.

Brown, J.E., H.A. Fitzhugh, Jr and T.C. Cartwright : 1976, A comparison of nonlinear models for describing weight-age relationships in cattle, J. Anim. Sci., 42, 810-818.

BRoDy, S. : 1945, Time relations of growth individuals and populations, In Bioenergetics and Growth. 500, Hafner Publishing, New York.

Fitzhugh, H. A. JR. : 1976, Analysis of growth curves and strategies for altering their shape, J. Anim. Sci., 42, 1036-1051.

Gompertz, B. : 1825, On the nature of the function expressive of the law of human mortality, and on a new mode of determining the value of life contingencies, Philos. Trans. Royal Soc., 115, 513- 
583.

Hastie, T., R. Tibshirani and J. Friedman : 2009, Model assessment and selection, In the Elements of Statistical Learning: Data mining, Inference, and Prediction. 2nd ed. 241-249, Springer, New York.

Kebreab, E., M. Schulin-Zeuthen, S. Lopez, J. Soler, R.S. Dias, C.F.M. De Lange and J. France : 2007, Comparative evaluation of mathematical functions to describe growth and efficiency of phosphorus utilization in growing pigs, J. Anim. Sci., 85, 2498-2507.

Köhn, F., A.R. Sharifi and H. Simianer : 2007, Modeling the growth of the Goettingen minipig, J. Anim. Sci., 85, 84-92.

Luo, J., H. Lei, L. Shen, R. Yang, Q. Pu, K. Zhu, M. Li, G. TAng, X. Li, S. Zhang and L. Zhu : 2015, Estimation of growth curves and suitable slaughter weight of the Liangshan pig, Asian-Australas. J. Anim. Sci., 28, 1252-1258.

NARO (National Agriculture and Food Research Organization) : 2013, Japanese feeding standard for swine (2013), 47, Japan Livestock Industry Association, Tokyo.

Okinawa Agu Brand Pork Promotion Council : 2008, The manual for Feeding Managing Okinawa Agu pig [homepage on the Internet], 3. Agu Brand Pork Promotion Council, Okinawa: [Cited 22 march 2020]. Available from URL : http://okinawa-agu.com/assets/files/breeding_ manual.pdf

R Core Team : 2017, R : A language and environment for statistical computing, R Foundation for Statistical Computing, Vienna, Austria, URL : http://www.r-project.org/.

Selvaggi, M., V. Laudadio, A.G. D’Alessandro, C. Dario and V. Tufarelli : 2017, Comparison on accuracy of different nonlinear models in predicting growth of Podolica bulls, Anim. Sci. J., 88, 1128-1133.

Strathe, A.B., A. Danfaer, H. Sørensen and E. Kebreab : 2010, A multilevel nonlinear mixedeffects approach to model growth in pigs, J. Anim. Sci., 88, 638-649.

Touma, S., M. Onaga, N. Toubaru and T. Oikawa : 2017 , Breed characteristics of indigenous pigs in Okinawa: growth performance, carcass traits and meat quality, Jpn. J. Swine Sci., 54, 121-129.

Touma, S. and M. Oyadomari : 2020, Comparison of growth performances, carcass characteristics, and meat qualities of Okinawan indigenous Agu pigs and crossbred pigs sired by Agu or Duroc boar, Anim. Sci. J., 91, e13362.

von Bertalanffy, L. : 1957, Quantitative laws in metabolism and growth, Q. Rev. Biol., 32, 217231.

Wellock, I.J., G.C. Emmans and I. Kyriazakis : 2004, Describing and predicting potential growth in the pig, Anim. Sci., 78, 379-388. 


\title{
5 つの発育曲線モデルによる沖縄アグー種 雄豚の発育様相の検討
}

\author{
當眞嗣平 ${ }^{1,2} \cdot$ 親泊元治 ${ }^{1,2}$ \\ ${ }^{1}$ 沖縄県畜産研究センター, 沖縄県今帰仁村 905-0426 \\ 2 現所属）沖縄県畜産課，沖縄県那覇市泉崎 1-2-2 \\ (2020 年 7 月 1 日受付, 2020 年 9 月 7 日受理)
}

\begin{abstract}
要 約アグーは, 発育は遅いものの優れた肉質を持つ豚であり, 西洋系品種雌に止め雄と してアグーを利用する銘柄豚肉生産も広く行われている。本試験では, アグー種雄豚の発育様 相を明らかにするため, 生時から 34 週齢までの体重記録に Logistic, Gompertz, von Bertalanffy, Richards およびJanoschek の 5 種類の発育曲線モデルを当てはめた。アグー雄 14 頭 を用い 16 週齢までは不断給餌，16 週齢以降は $1.5 \mathrm{~kg} /$ 日の制限給餌を行った。体重は 1 週間間 隔で測定した。いずれの発育曲線も $\mathrm{S}$ 字型の曲線を示した。発育曲線の適合度を自由度調整済 決定係数 $\left(\mathrm{Adj}^{2}\right)$ と赤池の情報量基準（AIC）でみると，Richards モデルが最も優れていた。 また， Leave-one-out 交差検証による予測精度の検証でも， Richards モデルの二乗平均平方根 誤差（RMSE）が最も小さく予測精度が高かった。Richards モデルで推定された変曲点到達 週齢は 11.6 週齢であり, 変曲点体重と変曲点増体速度はそれぞれ, $29.6 \mathrm{~kg}, 496.9 \mathrm{~kg} / \mathrm{day}$ であっ た。
\end{abstract}

キーワード：沖縄アグー豚，発育曲線，種雄豚，体重，非線形モデル 